\title{
The influence of the vegetative stage of Galega orientalis on the quality of haylage prepared from it
}

\author{
Boris Starkovskiy ${ }^{1,}$, Gennadiy Simonov ${ }^{2}$, Yuliya Malinovskaya ${ }^{1}$, and Aleksandr Simonov ${ }^{3}$ \\ ${ }^{1}$ The Vereshchagin Vologda State Dairy Farming Academy, Schmidt St., 2, 160555 Vologda, Russia \\ ${ }^{2}$ The Vologda Scientific Center of the Russian Academy of Sciences, Lenin St., 14, 160555 Vologda, \\ Russia \\ ${ }^{3}$ National Research University "Higher School of Economics", Myasnitskaya St., 20, 101000 \\ Moscow, Russia
}

\begin{abstract}
Studying the effect of plant raw materials on the quality of the finished haylage made of Galega orientalis when preparing it at different vegetative stages of plants. Special attention is paid to haylage in the livestock ration structure because compared to silage it has higher nutritive value and contains more dry matter, protein, sugars, macro- and microelements, as well as biologically active substances. It is worth to note that haylage rations have a beneficial impact on the animal body and the productivity of animals, which, in turn, reduces production costs. it has been proved that the green mass of Galega orientalis is a good raw material for making haylage if the technological requirements for feed preparation are met.
\end{abstract}

\section{Introduction}

The profitability of animal husbandry directly depends on the quality and cost of feed, the nutritional value of which is as close as possible to that of the original plant raw materials [1-4].

Nutritionally, haylage covers a considerable proportion in the livestock ration structure. It is good to taste and is readily eaten by animals, which reflects positively on productivity. At present more and more attention is paid to haylage because compared to silage it has higher nutritive value and contains more dry matter, protein, sugars, macro- and microelements, as well as biologically active substances. It is worth to note that haylage rations have a beneficial impact on the animal body. Well-prepared feed rations have a positive effect on the physiological and reproductive functions of the animal body, contribute to the cost efficiency of the feed [5-16, 19-21]. That's why haylage deserves special attention.

It should be remembered that the main criterion in making haylage is the moisture content of the raw material $[17,18]$. In addition to moisture, sugar-protein ratio should be strictly monitored, and forage harvesting should be carried out at the optimal time of

\footnotetext{
* Corresponding author: bor.2076@yandex.ru
} 
mowing ripeness. Galega orientalis due to its biological peculiarities ranks high among fodder crops.

The aim of our research was to study the influence of the plant raw material on the quality of the finished haylage made of Galega orientalis at different vegetation stages, and based on the results received in the experiment offer suggestions on more effective production of feed from plant raw material.

\section{Materials and methods}

The research was carried out in the Vereshchagin Vologda State Dairy Farming Academy. The material for the research was the green mass of Galega orientalis at various stages of vegetation while making haylage. During the research a generally accepted method was used to define dry matter content, lactic, acetic and butyric acids, metabolizable energy, digestible protein, and quality grade of feed in the finished haylage.

\section{Results and discussion}

The content and the ratio of acids in haylage made of Galega orientalis are shown in (table1).

Table 1. The effect of Galega orientalis vegetative stage on the quality indicators of the finished haylage

\begin{tabular}{|c|c|c|c|c|}
\hline Vegetative stages & Dry matter, \% & \multicolumn{3}{|c|}{ Acids content in the dry matter, \% } \\
\cline { 3 - 5 } & & Lactic & Acetic & Butyric \\
\hline $\begin{array}{c}\text { Budding - beginning of } \\
\text { blooming }\end{array}$ & 42.4 & 68.0 & 32.0 & 0 \\
\hline $\begin{array}{c}\text { Full blooming - } \\
\text { beginning of fruit } \\
\text { formation }\end{array}$ & 47.1 & 71.0 & 29.0 & 0 \\
\hline $\begin{array}{c}\text { Grass of the second } \\
\text { mowing }\end{array}$ & 42.6 & 81.4 & 18.6 & 0 \\
\hline
\end{tabular}

Table 1 shows that the highest dry matter content in the finished fodder was found in the haylage made of Galega orientalis at the phase of 'full blooming - beginning of fruit formation'. The haylage samples made of Galega orientalis at other phases of mowing ripeness did not show any practical differences between them.

The lactic acid ratio is higher than that of acetic acid in the finished haylage samples made of the raw material of different vegetation phases. Butyric acid is absent, which indicates the good quality of the feed.

Qualitative indicators of Galega orientalis haylage are given in (table 2).

Table 2. Qualitative indicators of Galega orientalis haylage (in $1 \mathrm{~kg}$ of absolutely dry matter)

\begin{tabular}{|c|c|c|c|c|}
\hline \multirow[b]{3}{*}{ Indicator } & \multirow[b]{3}{*}{ Standard } & \multicolumn{3}{|c|}{ Haylage made of plants } \\
\hline & & Of the main & ag in the phase of: & grass of \\
\hline & & $\begin{array}{l}\text { budding - } \\
\text { beginning of } \\
\text { blooming }\end{array}$ & $\begin{array}{l}\text { full blooming - } \\
\text { beginning of fruit } \\
\text { formation }\end{array}$ & $\begin{array}{c}\text { the } \\
\text { second } \\
\text { mowing }\end{array}$ \\
\hline
\end{tabular}


Table 2. Continued

\begin{tabular}{|l|c|c|c|c|}
\hline $\begin{array}{l}\text { Metabolizable } \\
\text { energy, MJ }\end{array}$ & 9.6 & 10.4 & 10.3 & 8.1 \\
\hline Digestible protein, g & 112.5 & 145.9 & 142.1 & 91.1 \\
\hline Quality grade & 1 & 1 & 1 & 2 \\
\hline
\end{tabular}

Table 2 illustrates that the highest nutritive value of the finished haylage made of Galega orientalis was the one found in the raw materials prepared from plants at the phase of 'budding - the beginning of blooming' - 10.4 MJ, and the lowest - from the grass of the second mowing $-8.1 \mathrm{MJ}$. Raw materials obtained from the plants cut at the phase of 'full blooming - the beginning of fruit formation' took an intermediate position in metabolisable energy in the finished fodder between the raw material prepared from plants at the phase of 'budding - the beginning of blooming' and at the phase of 'grass of the second mowing'.

It is possible to harvest the green mass of Galega orientalis for haylage with a set of a complex of machines [22].

The set of technological operations is based on following a number of requirements and conditions, and, as a rule, includes:

- Mowing. Depending on weather conditions and biomass yield with flattening or without it.

- $\quad$ Turning for simultaneous drying of stalks and leaves.

- Swathing.

- Grinding the mass to fodder (depends on the type of storage; for example, when stored in a tower it should be ground up to $3 \mathrm{~cm}$, in a trench - to $5 \mathrm{~cm}$ ).

- The mass should be pressed constantly with heavy wheeled equipment till it is covered. Pressing should be done carefully, especially at the walls of storage facilities;

The mass should be laid daily with a height of 1 meter. The laying time should not exceed 4 days.

- After laying the fodder it should be protected from the penetration of oxygen by sealing it.

- The moisture content of the green mass during laying haylage should be controlled, and if this control is impossible the visual observation method is used. This method is based on the ability of haylage plants to extract juice when twisting them into a bundle. If the juice is not extracted, but the hand becomes wet, the moisture content is $55-60 \%$. If the mass is over-dried, the leaves become brittle and crumble (40-45\%).

Evaluating the finished fodder on qualitative indicators is carried out after 1-1.5 months in laboratory conditions (full zootechnical analysis).

\section{Conclusions}

The experiments have proved the possibility of getting high quality fodder - haylage made of Galega orientalis. The analysis of the content and ratio of acids in Galega orientalis haylage depending on the vegetative stage of the mowed plant shows the favorable ratio of acids at the phase of 'full blooming - beginning of fruit formation' and when preparing feed from the second mowing grass, with the lactic acid content of 71 and $81.4 \%$ respectively. By the nutritional value of the feed $(8.1 \mathrm{MJ})$ and the amount of digestible protein $(91.1 \mathrm{~g} / \mathrm{kg}$ of the dry matter) the haylage made of the second mowing grass was inferior to all the studied options. That's why the phase of 'full blooming - beginning of fruit formation' should be considered a favorable period for mowing Galega orientalis plants for making haylage if the technological requirements for feed preparation are met. 


\section{References}

1. B. N. Starkovskiy, Ivan-tea narrow-leaved: biology, technology, economic use (2018)

2. F.S. Khaziakhmetov, Annual Research \& Review in Biology, 25(1), 1 (2018)

3. I. V. Mironova, Research Journal of Pharmaceutical, Biological and Chemical Sciences, 9(6), 18 (2018)

4. B. N. Starkovsky, G. A. Simonov, Yu. N. Malinovskaya, E3S Web of Conf., 176, 03004 (2020)

5. D. Gayirbegov, Comp. Feed. 12, 63 (2015)

6. V. S Zoteyev, Animal Husbandry, 5, 45 (1985)

7. A. P. Kalashnikov, Rep. of the All-Union Ac. of Agric. Sc., 11, 29 (1984)

8. M. Magomedov, Dairy and meat cattle breeding, 1, 11 (1993)

9. G. A. Simonov, Zootech, 12, 30 (1988)

10. G. A. Simonov, M. E. Gulyaeva, A. G. Simonov, Scientific support of the agroindustrial complex of the Euro-North-East of Russia, 177 (2010)

11. G. A. Simonov, P. A. Aligaziyeva, Tips for dairy cattle farmers (2011)

12. G. Simonov, Dairy and meat cattle breeding, 4, 19 (2011)

13. G. A. Simonov, Scientific and practical ways to improve environmental sustainability and socio-economic support of agricultural production, 1369 (2017)

14. E. Tyapugin, Dairy and meat cattle breeding, 3, 2 (2010)

15. E. A. Tyapugin, Rep. of the Rus. Acad. of Agric. Sc., 3, 50 (2015)

16. A. Ushakov, Comp. Feed. 12, 81 (2016)

17. A. S. Ushakov, Effic. anim. husb., 6 (136), 46 (2017)

18. B. N. Starkovskiy, N. I. Kapustin, Promising directions of scientific research of young scientists of the North-West of Russia, 114 (2001)

19. V. V. Shcheglov, L. G. Boyarskiy, Directory of feed: preparation, storage, use (1990)

20. E. Tyapugin, Dairy and meat cattle breeding, 5, 23 (2011)

21. E. A. Tyapugin, Directory of chemical composition and nutritional value of forages of Vologda region (2017)

22. G. A. Simonov, V. M. Kochetkov, V. S. Zoteyev, P.I. Solov'yov, Proceedings of the Orenburg State Agrarian University, 3(27), 113 (2010) 